\title{
Molecular Phylogeny and Genetic Diversity of Domestic Yaks (Bos grunniens) in Pakistan based on Mitochondrial and
} Microsatellite Markers

\author{
T. Hussain ${ }^{\gamma}$, A. Wajid', M. Soail, A. Ali, K. Abbas, F. M. M. T. Marikar*, \\ M. M. Musthafa and M. E. Babar
}

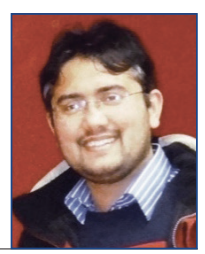

\begin{abstract}
The complete Cytchrome b gene and partial mtDNA control region were sequenced for the Pakistani domestic yak (Bos grunniens) within the Bovidae family. A total of 300 samples were genotyped using 27 bovine microsatellite markers from the Gilgit-Baltistan and Skardu regions of Pakistan. We identified a total of 35 mutations and 9 haplotypes based on D-loop sequences, with a haplotype and nucleotide diversity of $0.9640 \pm 0.051$ and $0.02172 \pm 0.00224$, respectively. For the Cyt $b$ gene, a total of 23 variable sites and six different haplotypes were observed with $0.885 \pm 0.067$ haplotype and $0.00989 \pm 0.003$ nucleotide diversity. Phylogenetic analysis of D-loop and Cyt $b$ gene suggested that domestic yak sequences
\end{abstract}

cluster into two highly divergent maternal lineages (lineages I and II), while three haplogroups A, C, and D were identified of the six previously known haplogroups. Haplogroups A and C were dominant and widely distributed among all investigated yak samples. All microsatellites were polymorphic and a total of 138 alleles were observed, with average polymorphic information content (PIC) of 0.56 indicating their effectiveness. The average heterozygosity was observed at 0.6071 with allele diversity of 5.1111 and gene diversity of 0.4830 . The implications of these findings can be applied for yak conservation.

Key words: domestic yak; mtDNA D-loop; Cyt b gene; microsatellites; phylogeny; Pakistan

Tanveer HUSSAIN, Abdul WAJID, Akhtar ALI, Kamran ABBAS, Ellahi BABAR, The University of Agriculture, Dera Ismail Khan, Khyber, Pakhtunkhwa, Pakistan; Mudassir SOAIL, Department of Livestock and Dairy Development, Gilgit Baltistan, Pakistan; Faiz M. M. T. MARIKAR*, DVM, PhD, (Corresponding author, e-mail: faiz@kdu.ac.lk), General Sir John Kotelawala Defense University, Ratmalana, Sri Lanka, ${ }^{*}$ The Open University of Sri Lanka, Faculty of Health Sciences, Nawala Sri Lanka*; Muneeb M. MUSTHAFA, Department of Biosystems Technology, Faculty of Technology, South Eastern University of Sri Lanka, University Park, Oluvil, Sri Lanka

$\gamma$ First two authors contributed equally 


\section{Introduction}

Yak (Bos grunniens) is a member of the Artiodactyla, family Bovidae and genus Bos. Yak can be considered to be one of the world's most significant domestic animals, as it can survive in extreme environments and ensures a livelihood for the local people. Domestic yak is distributed at high altitudes between 2000 to $5000 \mathrm{~m}$, in areas of the Hindu Kush and Karakoram in Pakistan and Afghanistan, Himalayas in India, Nepal, Tibetan plateau and Tien Shan mountains of northwestern China and western and northern Mongolia (Miller and Steane, 1997). Yaks are multipurpose animals providing products such as milk, meat, leather, hair and manure for fuel for people living at high altitudes, and are useful as riding and pack animals (Nguyen et al., 2005). The domestic yak is one of the most significant domestic animal genetic resources in the corresponding region and plays a vital role in the life of pastoralists and agro-pastoralists (Wiener et al., 2003). Indispensable knowledge of the genetic variability of the yak population is useful for conservation efforts to protect yak genetic resources. The principal objective of breeding yaks and other livestock is to improve productivity and fitness, and to influence desirable changes in the animal's genome (Nguyen et al., 2005). Unfortunately, quantitative genetic characterization has been largely absent for the yak because of the unavailability of pedigree data and performance records in yak populations. Other reasons may be due to the remoteness and harsh conditions of yak territories, and the care of the yak. To design typical breeding strategies for the optimum utilization and conservation of genetic variability of Pakistani yak population, it is crucial to understand their genetic architecture and variation. To obtain knowledge of their genetic structure, we utilized molecular markers such as mitochondrial displacement loop, Cytochrome $b$ gene and bovine microsatellite markers.

In Pakistan, yak pastoralism is restrained to the Northern highlands i.e. Skardu district, Astore in district Diamer and Ganche districts in Baltistan and Chitral regions, lying at altitude of $3100 \mathrm{~m}$. Yaks are endemic to the vast mountainous regions characterized by cold and high altitude environments of Hindu Kush and Karakoram highlands of Pakistan and Afghanistan, bordered on Xinjiang and Qinghai-Tibetan Plateau (QTP) and their distribution extends into central Asia to Afghanistan, Tajikistan and to the Hangai, Hovsgol, Altai and Hentii mountains of Mongolia and Altai, East and West mountains of Sayan (Buryatia and Republics of Tuva, respectively) Russia and some of the central independent states of the former USSR.

Mitochondrial DNA is a useful genetic marker for both intra and interspecies studies (Loftus et al., 1994; Kikkawa et al., 1995). Mitochondrial DNA (mtDNA) contains highly informative polymorphic sites and in many organisms its simple maternal inheritance without recombination makes it useful for population studies (Luikart et al., 2001). The mitochondrial genome (mtDNA) of vertebrates has become a common tool for resolving phylogenetic relationships at different evolutionary depths due to its distinctive properties (Carmela et al., 2000). The current study was planned to use the mitochondrial Cytochrome $b$ and D-loop region for the genetic diversity and phylogenetic analysis of Pakistani yak populations. The most recent studies on the domestication patterns and phylogenetic histories of ungulate domestic animals have been based on the mtDNA D-loop region (Lau et al., 1998; Luikart et al., 2001; Troy et al., 2001; 
Jansen et al., 2002; Savolainen et al., 2002; Kierstein et al., 2004; Larson et al., 2005; Guo et al., 2006; Wang et al., 2010; Babar et al., 2011). This mitochondrial region is highly variable and informative in elucidating the origin of domestication, diversification and phylogenetic analysis of animals.

For microsatellites (or short tandem repeats), some authors have claimed that single nucleotide polymorphisms may more be well-known and are stable, polymorphic, easily analysed and occurs throughout an animal genome, making them especially suitable for genetic analysis (Boyce et al., 1996). Microsatellites are used as valuable genetic markers for genetic and population studies, assessment of the population relationship, identification of animals, parentage determination, determination of genetic variation within and among breeds, reconstruction of phylogenetic relationships among populations, disease diagnostics, forensic analysis, development of genetic maps, and in marker-assisted breeding.

In the present study, we performed a preliminary analysis based on mitochondrial DNA (mtDNA) and microsatellite markers to characterize the genetic diversity of domestic yaks reared across the Northern region of Pakistan. This study will aid future conservation efforts and breeding programmes of domestic yak to improve meat quality and milk yields.

\section{Materials and Methods Blood collection, DNA extraction and Ethics clearance}

Blood samples $(10 \mathrm{~mL})$ were collected from 300 yaks from Gilgit-Baltistan $n=18$ and Sakardu $n=7$ in ethylenediamine tetra-acetic acid (EDTA) added tubes. The inorganic method (Sambrook and Russell, 2001) was used for genomic DNA extraction. The final concentration of
DNA was brought to $50 \mathrm{ng} / \mathrm{uL}$ and stored at $-80^{\circ} \mathrm{C}$, before further use. Approval from the Institutional Animal Care and Use Committee (IACUC) from Virtual University of Pakistan was obtained before the experiment.

\section{Mitochondrial genome analysis}

To amplify the complete mitochondrial Cyt $b$ gene (1609 bp), three pairs of primers were designated from Bos indicus (NCBI accession number AF492350) using software Primer3 (Steve and Skaletsky, 2000). Primer set 1: MtCCF1 (5'-CGAAAGTCCCACCCACTAAT-3') and MtCCR1 (5'-TCCTCATGGTAGGACGT ATCC-3'); primer set 2: MtCCF2 (5'-GCACGTAGGACGAGGCTT AT $3^{\prime}$ ) and MtCCR2 (5'-AAGAGGGCCCCTAAGATGTC-3'); primer set 3: MtCCF3 (5'-AAATCCCATTCCACCCTAC-3') and MtCCR3 (5'-GTGCCGGCTGTTGGTATTAG-3'). The partial mtD-loop region of $695 \mathrm{bp}$ was amplified using two sets of oligos, set 1: MtCDF1 (5'-TCCATAAATACAAAGAGCCTTATCAGT-3') and MtCDR1 (5'-GCGGCAT GGTAATTAAGCTC-3'), and set 2: MtCDF2 (5'-TTATATATTCCCTACCATTAGATCACG-3') and MtCDR2 (5'- GGGAAAAGTCTGTTAAAA GTGGTG-3'), designated from Bos indicus: accession number AF492350. PCR was performed in a $25 \mu \mathrm{L}$ reaction mixture containing $1 \mu \mathrm{L}$ template (the genomic DNA of each sample was used as a template for PCR), $1 \mu \mathrm{L}$ each primer $(10 \mathrm{pmoL} / \mu \mathrm{L}), 12.5 \mu \mathrm{L}$ of $2 \times$ Taq PCR MasterMix and $9.5 \mu \mathrm{L}$ ddH2O. Negative controls were always included in PCR reactions to assess possible contamination.

The standard PCR conditions for Cyt $b$ were followed: initial denaturation temperature at $95{ }^{\circ} \mathrm{C}$ for $4 \mathrm{~min}, 35$ cycles of denaturation at $94{ }^{\circ} \mathrm{C}$ for $30 \mathrm{~s}$, annealing at $57.2{ }^{\circ} \mathrm{C}, 59{ }^{\circ} \mathrm{C}, 61^{\circ} \mathrm{C}$ for 30 $\mathrm{s}$ for primer sets 1,2 and 3 , respectively, and extension at $72{ }^{\circ} \mathrm{C}$ for $45 \mathrm{~s}$ followed by final extension at $72^{\circ} \mathrm{C}$ for $10 \mathrm{~min}$. PCR was performed in $25 \mu \mathrm{L}$ reaction mixture 
using about 50 ng DNA as a template with 2 units Taq DNA polymerase (Fermentas, Thermo Fisher Scientific Inc. USA). For D-loop, PCR was performed using initial denaturation at $95{ }^{\circ} \mathrm{C}$ for 4 $\mathrm{min}$, and then 35 cycles of denaturation at $94{ }^{\circ} \mathrm{C}$ for $30 \mathrm{~s}$, annealing at $59{ }^{\circ} \mathrm{C}$ for $30 \mathrm{~s}$, and extension at $72{ }^{\circ} \mathrm{C}$ for $45 \mathrm{~s}$, followed by final extension at $72{ }^{\circ} \mathrm{C}$ for $10 \mathrm{~min}$. For PCR, $25 \mu \mathrm{L}$ reaction mixtures were used using 50 ng DNA as a template and 1 unit Taq DNA polymerase. The PCR product was purified by ethanol precipitation and sequenced using an automated 300 DNA sequencer ABI PRISM ${ }^{\circledR} 3130 X 1$ Genetic Analyzer (Applied Biosystem Inc, Foster City, CA).

\section{Phylogenetic analysis}

The newly determined complete mitochondrial Cyt $b$ gene and partial D-loop sequences from Pakistani domestic yaks were submitted in GenBank for the Cyt $b$ gene and for D-loop. Phylogenetic analysis was carried out on the basis of selected Pakistani domestic yaks, with 135 mtDNA D-loop sequences selected from GenBank NCBI from both domestic and wild yaks belonging to different geographical regions and breeds. We constructed a Neighbour-Joining phylogenetic tree that included the reference sequences from six formally recognised haplogroups (A, B, C, D, E, and F) identified by Guo et al. (2006) and Wang et al. (2010). The phylogenetic tree was constructed using MEGA6 (Tumara et al. 2013). We further constructed a short Maximum-Likelihood phylogenetic tree on the basis of both complete Cyt $b$ and partial D-loop to determine the phylogenetic relationship of yak with different genera of Bovinae. For the analysis based on the Cyt $b$ gene, GenBank sequences used for Bovinae were as follows: Bos grunniens (domestic yak) accession numbers AY684273, AY374124, AF09163; Bos mutus (wild yak) accession numbers AY955225, AY955226; Bison bison
(American bison) accession numbers JN632601, GU947005; Bison bonasus (European bison) accession number Y15005, AY689186; Bos taurus (cattle) accession numbers V00654, FJ971086; Bos indicus (Zebo cattle) accession numbers NC005971, and AF492350; Bubalus bubalis (Asian buffalo) accession number NC006295. Capra hircus (domestic goat) accession number GU295658 was used as an outgroup, since this was one of the first domesticated animal species. For further confirmation, a short phylogenetic tree based on partial D-loop region was constructed, with the following Genbank sequences: Bos grunniens (domestic yak) accession number NC006380; Bos mutus (wild yak) FJ548844; American Bison (Bison bison) JN632601; Bison bonasus (European bison) JN632602; cattle Bos taurus V00654; Bos indicus (Zebo cattle) NC005971 and Capra hircus GU295658 as outgroup.

\section{Microsatellite genotyping}

A set of 27 microsatellite markers distributed across the bovine genome and showing polymorphism in cattle were selected for the diversity analysis of yak in this study. All markers (ETH10, INRA005, ILSTS029, ILSTS033, ILSTS044, ILSTS049, ILSTS052, INRA63, ETH225, BM6526, CSSM66, HAUT27, BM1824/1, BM2113, TGLA227/18, INRA023, SPS115, TGLA122/21, TGLA126, INRA32, BM1818, and ILSTS011, MAF70, MAF33, MM12, ETH152 and OarFCB48) were labelled with fluorescent dyes at the $5^{\prime}$ end of the forward primer with FAM, PET, NED or VIC (Table 1). PCR amplification was done in BioRad thermo-cycler using a reaction mixture of $25 \mathrm{uL}$ containing $50 \mathrm{ng}$ template DNA, $50 \mathrm{mM} \mathrm{KCl}, 10 \mathrm{mM}$ Tris- $\mathrm{HCl}, 2.5 \mathrm{mM}$ dNTPs, $1.5 \mathrm{mM} \mathrm{MgCl}_{2}, 0.75$ pmoL of each forward and reverse primers, and 2U Taq polymerase (Fermentas, Thermo Fisher Scientific Inc. USA). PCR conditions were as follows; initial denaturation at $95{ }^{\circ} \mathrm{C}$ 
Table 1. Microsatellite loci analysed, PCR condition, size ranges and chromosome number in yak (Bos grunniens)

\begin{tabular}{|c|c|c|c|c|c|c|}
\hline Sr. No & Marker & Dye & $\begin{array}{l}\text { Chrom. } \\
\text { No. }\end{array}$ & Allele range & $\begin{array}{l}\text { Anealing } \\
\text { Temp. }\end{array}$ & Sequence $5^{\prime}-3^{\prime}$ \\
\hline \multirow{2}{*}{1} & \multirow{2}{*}{ BM1818 } & \multirow{2}{*}{ 6-FAM } & \multirow{2}{*}{23} & \multirow{2}{*}{$254-271$} & \multirow{2}{*}{$52-62$} & AGCTGGGAATATAACCAAAGG \\
\hline & & & & & & AGTGCTTTCAAGGTCCATGC \\
\hline \multirow{2}{*}{2} & \multirow{2}{*}{ BM1824 } & \multirow{2}{*}{ 6-FAM } & \multirow{2}{*}{1} & \multirow{2}{*}{$178-190$} & \multirow{2}{*}{$52-62$} & GAGCAAGGTGTTTTTCCAATC \\
\hline & & & & & & САTTCTCCAACTGCTTCCTTG \\
\hline \multirow{2}{*}{3} & \multirow{2}{*}{ BM2113 } & \multirow{2}{*}{ NED } & \multirow{2}{*}{2} & \multirow{2}{*}{$132-136$} & \multirow{2}{*}{$52-62$} & GCTGCCTTCTACCAAATACCC \\
\hline & & & & & & CTTCCTGAGAGAAGCAACACC \\
\hline 4 & & & - & & $52-62$ & CATGCCAAACAATATCCAGC \\
\hline 4 & BMO5:0 & HEX & - & $140-134$ & $3 \angle-62$ & TGAAGGTAGAGAGCAAGCAGC \\
\hline 5 & CSSM66 & 6-FAM & 14 & $187-193$ & $52-62$ & ACACAAATCCTTTCTGCCAGCTGA \\
\hline 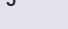 & 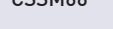 & $0-r$ AIV & 14 & $108-175$ & $32-62$ & AATTTAATGCACTGAGGAGCTTGG \\
\hline 6 & ETH10 & PET & 5 & $211-222$ & $52-62$ & GTTCAGGACTGGCCCTGCTAACA \\
\hline 0 & Linto & ET & J & $211-2 \angle 2$ & $32-02$ & ССТCCAGCCСАСТTTCTCTTCTC \\
\hline 7 & ETH225 & VIC & 9 & $142-152$ & $52-62$ & GATCACCTTGCCACTATTTCCT \\
\hline 1 & EIH $2 \angle 0$ & VIT & 4 & $144-152$ & $5 Z-6 Z$ & ACATGACAGCCAGCTGCTACT \\
\hline 8 & & & 26 & $145-157$ & 51 & TTTTATGTTCATTTTTTGACTGG \\
\hline 8 & HAULI & VIT & $\angle 0$ & $143-15 /$ & 31 & AACTGCTGAAATCTCCATCTTA \\
\hline 9 & ॥ STS011 & PET & 14 & $266-269$ & $52-62$ & GCTTGCTACATGGAAAGTGC \\
\hline r & 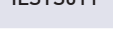 & LT & 14 & $200-201$ & $3 L-0 Z$ & CTAAAATGCAGAGCCCTACC \\
\hline 10 & ILSTS029 & VIC & 3 & $155-163$ & $52-62$ & TGTTTTGATGGAACACAGCC \\
\hline 10 & 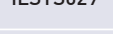 & vic & 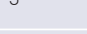 & (1) & $3 L-0<$ & TGGATTTAGACCAGGGTTGG \\
\hline & & & & & & TATTAGAGTGGCTCAGTGCC \\
\hline T1 & ILSISU33 & 6-FAM & 12 & $148-164$ & $52-62$ & ATGCAGACAGTTTTAGAGGG \\
\hline 12 & IST044 & HEX & 3 & $129-131$ & 51 & AGTCACCCAAAAGTAACTGG \\
\hline 12 & ILSTO44 & HEX & 3 & $124-|3|$ & 31 & ACATGTTGTATTCCAAGTGC \\
\hline 13 & II STSO49 & NFD & 11 & $158-172$ & $52-62$ & САATTTTCTTGTCTCTCССC \\
\hline 10 & ILS13049 & NEE & 11 & $150-1 / 2$ & $5 \angle-62$ & GCTGAATCTTGTCAAACAGG \\
\hline 14 & ILSTS052 & PET & 21 & $136-152$ & $52-62$ & CTGTCCTTTAAGAACAAACC \\
\hline 14 & 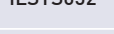 & LT & 21 & $100-102$ & & TGCAACTTAGGCTATTGACG \\
\hline & & & & $123-129$ & & CAGGCATACCCTACACCACATG \\
\hline 15 & INRAUUS & NED & 12 & $123-124$ & $52-62$ & AAATATTAGCCAACTGAAAACTGGG \\
\hline 16 & INRA032 & VIC & 11 & $181-190$ & $52-62$ & AAACTGTATTCTCTAATAGCAC \\
\hline & INKAUSL & VIT & 11 & $101-190$ & $5<-62$ & GCAAGACATATCTCCATTCCTTT \\
\hline 17 & INRA063 & 6-FAM & 18 & $166-178$ & 54 & ATTTGCACAAGCTAAATCTAACC \\
\hline 11 & TINTHOOS & 0-7 tivi & 10 & 100-170 & 34 & AAACCACAGAAATGCTTGGAAG \\
\hline 18 & TGLA122 & NED & 21 & $108-116$ & $52-62$ & СССTCCTCCAGGTAAATCAGC \\
\hline & & & & & & AATCACATGGCAAATAAGTACATAC \\
\hline 19 & TGLA126 & VIC & 20 & $144-156$ & $52-62$ & CTAATTTAGAATGAGAGAGGCTTCT \\
\hline 19 & IGLAIZ6 & VIT & $\angle 0$ & $144-156$ & $5<-62$ & TTGGTCTCTATTCTCTGAATATTCC \\
\hline 20 & TGLA227 & 6-FAM & 18 & $83-86$ & 61 & CGAATTCCAAATCTGTTAATTTGCT \\
\hline & IOLALZI & $0-F A M$ & 10 & & 01 & ACAGACAGAAACTCAATGAAAGCA \\
\hline 21 & INRA023 & VIC & 3 & $141-155$ & $52-62$ & GAGTAGAGCTACAAGATAAACTTC \\
\hline 21 & TINAULO & VIc & 3 & $141-100$ & $32-02$ & TAACTACAGGGTGTTAGATGAACTC \\
\hline 22 & SPS115 & VIC & 15 & $136-150$ & $52-62$ & AAAGTGACACAACAGCTTCTCCAG \\
\hline & & & & & & AACGAGTGTCCTAGATTTGGCTGTG \\
\hline 23 & MAF70 & FAM & 4 & $140-170$ & $52-62$ & GCAGGACTCTACGGGGCCTTTGC \\
\hline 23 & MAF $T 0$ & FAM & 4 & $140-1 / 0$ & $5<-62$ & CACGGAGTCACAAAGAGTCAGACC \\
\hline 24 & MAF33 & NED & 9 & $129-161$ & $52-62$ & GATCATCTGAGTGTGAGTATATACAG \\
\hline & & & & & & GACTTTGTTTCAATCTATTCCAATTTC \\
\hline 25 & MM12 & FAM & 9 & $118-124$ & $52-62$ & CAAGACAGGTGTTTCAATCT \\
\hline & & & & & $3 L-02$ & ATCGACTCTGGGGATGATGT \\
\hline 26 & ETH152 & FAM & 5 & $154-182$ & $52-62$ & TACTCGTAGGGCAGGCTGCCTG \\
\hline & & & & & & GAGACCTCAGGGTTGGTGACAG \\
\hline 27 & OarFCB 48 & NED & 17 & $160-181$ & $60-60$ & GAGTTAGTACAAGGATGACAAGAGGCAC \\
\hline 27 & UarFCB 48 & NED & 17 & $100-181$ & $60-60$ & GACTCTAGAGGATCGAAAAGAACCAG \\
\hline
\end{tabular}


for 4 minutes, followed by 35 cycles of denaturation at $94{ }^{\circ} \mathrm{C}$ for $30 \mathrm{~s}$, annealing at 62 to $52{ }^{\circ} \mathrm{C}$ for $45 \mathrm{~s}$ and extension at $72{ }^{\circ} \mathrm{C}$ for $45 \mathrm{~s}$, followed by 10 minutes of extension at $72{ }^{\circ} \mathrm{C}$.

\section{Data analysis}

In analysing the genetic diversity in yak (Bos grunniens) using microsatellite loci, the number of observed and expected alleles, observed heterozygosity $\left(H_{\text {obs }}\right)$, expected heterozygosity $\left(H_{\text {exp }}\right)$ and Shannon (1949) information index as measure of genetic diversity were computed across the 27 loci using POPGENE version 1.31 (Yeh and Yong, 1999). GENEPOP version 4.0 (Raymond and Rousset, 1995) was also used to calculate the inbreeding coefficient $\left(\mathrm{F}_{\mathrm{IS}}\right)$ of an individual (I) relative to the subpopulation (S). The allele frequencies were utilized for the calculation of the polymorphic information content (PIC) using POWERSTAT V1.2.1 to determine the usefulness of marker.

\section{Results}

\section{Mitochondrial analysis}

After sequencing and alignment, the genetic diversity of domestic yak (Bos grunniens) through the mitochondrial control region partial sequences (695bp) identified a total of 35 mutations $(5.03 \%$ of 695 sites) and nine haplotypes (Fig. 1 ), of which haplotypes 1 and 7 were predominant with two sequences each, while the remaining haplotypes included only one sequence each. Among all variable sites, 9 were single variable and 26 were parsimony informative sites. Of the 35 variable sites, transition sites and transversion sites were expressed 28 times and 7 times, respectively, with a ratio (R) of 5:1. Haplotype (Hd) and nucleotide diversity (Pi) were $0.9640 \pm 0.051$ and $0.02172 \pm 0.00224$, respectively. We also analysed the complete mitochondrial Cyt $b$ gene in 300 domestic yaks. No insertions/deletions were observed. The average nucleotide frequencies of $\mathrm{T}, \mathrm{A}$, $C$ and $G$ were 26.1, 31.7, 29.1 and 13.1\%, respectively; the rate of $\mathrm{A} / \mathrm{T}(57.8 \%)$ was significantly higher than G/C (42.2\%). A notable imbalance in base usage was observed at the third position, with infrequent use of $\mathrm{G}(4.4 \%)$ and a bias towards $\mathrm{A}+\mathrm{C}(77.1 \%)$. The low number of Gs (4.4\%) and high number of As (42.2\%) at the third position indicate that the likelihood of an A to $G(5 \%)$ transition is much lower than a $\mathrm{G}$ to $\mathrm{A}(12.13 \%)$ transition. A total of 23 variable sites (2.01\% of 1140 sites) were observed (Fig. 1 ), of which 5 were single variable sites and 18 parsimony informative sites. Of the 23 variable sites, transition sites were expressed 22 times while transversion sites were expressed only once. The transition/ transversion ratio $(R)$ was 22 , showing a high transition bias. Interestingly, the transitional rate between pyrimidines (T-C) was higher than between purines (A-G), at a ratio of 5:1. Six haplotypes were observed from eleven complete Cyt $b$ gene sequences in Pakistani yak. The haplotype $(\mathrm{Hd})$ and nucleotide diversity (Pi) were $0.885 \pm 0.067$ and $0.00989 \pm 0.003$, respectively. Bootstrap support for each lineage and cluster for validity of the grouping. Ideally, supports less than $50 \%$ are not considered valid clusters or clades.

A phylogenetic analysis based on the partial control region sequences (695 bp) revealed that the Pakistani yak with other yak sequences included in the study fell into two highly divergent lineages (lineages I and II), where lineage I diverged into haplogroups $\mathrm{A}, \mathrm{B}$, and $\mathrm{E}$, and lineage II diverged into $\mathrm{C}, \mathrm{D}$, and F haplogroups. The Pakistani domestic yaks nested within both lineages I and II, within three identified haplogroups: A, C, and D (Fig 1).

In order to address the question raised in several studies (Corbet et al., 1978; Feng et al., 1986; Wiener et al., 2003; 


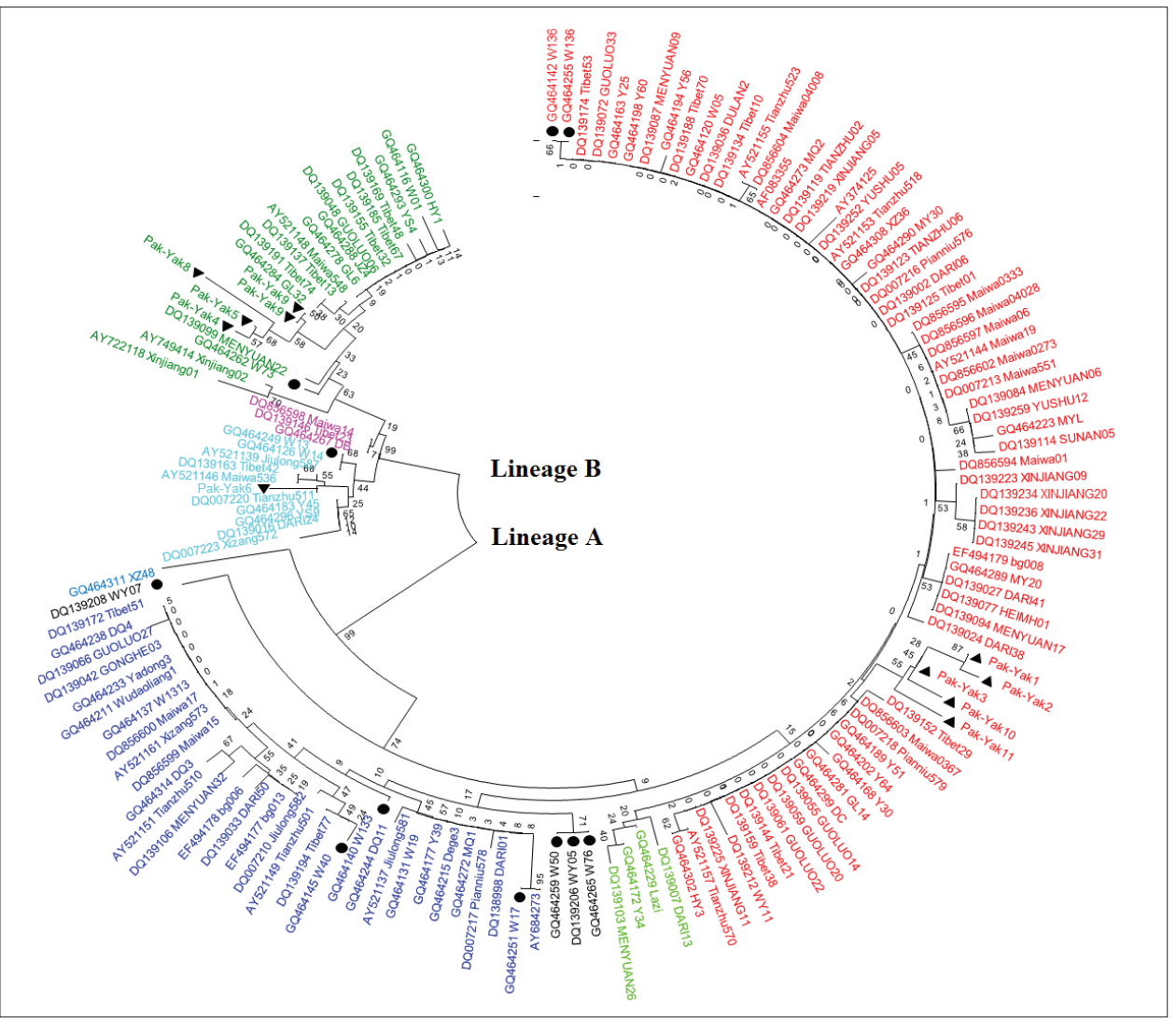

Figure 1. The phylogenetic analysis based on the partial mtDNA control region sequences of 143 domestic and wild yaks from the present study and remaining sequences retrieved from GenBank. The new PAK domestic yak sequences are denoted with a black triangle in the tree, while black circles represent wild yaks. The evolutionary history was inferred using the maximum likelihood method based on the General Reversible model (Nei and Kumar, 2000; Tamura et al., 2013).

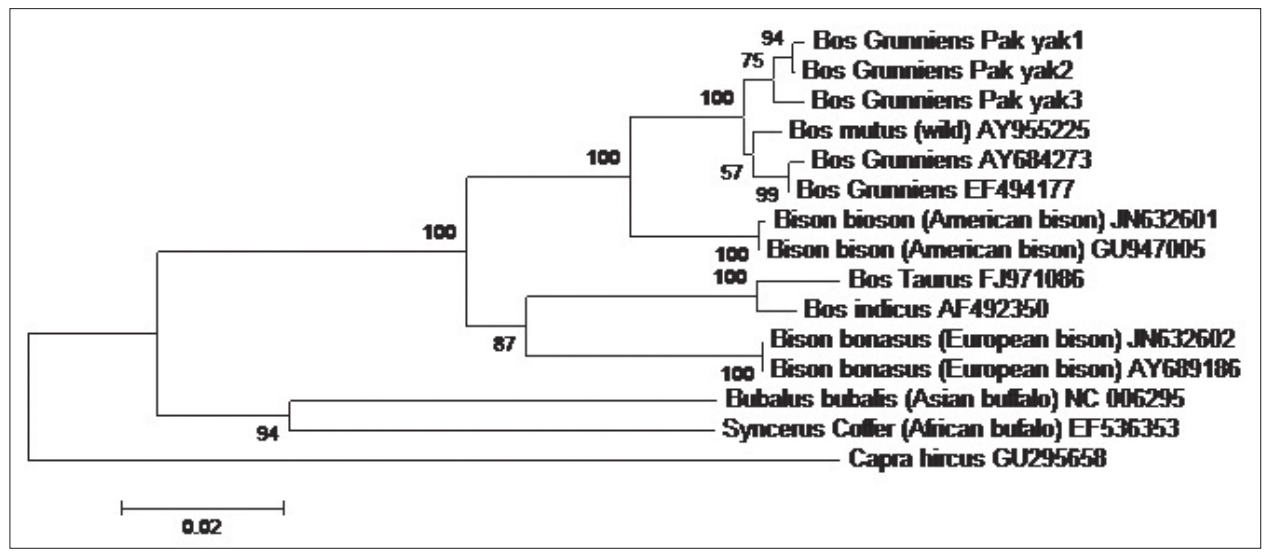

Figure 2. Phylogenetic analysis of yak by Neighbour-Joining tree 
Li et al., 2005; 2006) as to whether the yak belongs to a genus or sub-genus, we constructed a short Neighbour-Joining tree for the phylogenetic analysis of yak using Capra hircus (GenBank accession number GU295658) as an outgroup (Fig 2 ), and also computed genetic distance based on mtDNA control region using the p-distance model. There was high genetic comparability between Bos grunniens and Bos mutus $(4.6 \%)$ as compared to Bos indicus and Bos taurus (6.1\%) (Table 2). The mean sequence divergence between yak (Bos grunniens/ Bos mutus) and American bison (Bison bison) (6.5\%) was much lower than that between yak and the genus Bos (Bos indicus and Bos taurus) $(15 \%)$, indicating that the genetic correspondence between yak and American bison was much higher than that between yak and the genus Bos.

To explore further, we also sequenced and analysed the complete Cyt $b$ gene of
11 domestic yaks. The cytochrome $b$ gene data supported the analysis, as a very short genetic distance was found between Bos grunniens and Bos mutus $(0.8 \%)$, showing very high genetic similarity. The percentage of nucleotide sequence divergence between Bos grunniens and Bos mutus $(0.8 \%)$ was lower than that between Bos indicus and Bos taurus (1.6\%) (Table 3).

\section{Microsatellite amplification and genetic variability}

Genotypic data from a total of 27 autosomal bovine microsatellite markers were tested to assess the genetic structure of domestic yak (Bos grunniens). All the bovine microsatellite markers used in this study were successfully amplified with the right sizes of PCR products and were polymorphic ( $\geq 2$ alleles, Crawford et al., 1995, Table 4). A total of 138 alleles across the analysed 27 microsatellite loci

Table 2. Percentage of divergence for mtDNA Cyt $b$ gene sequences in Bovinae and the outgroup

\begin{tabular}{|c|c|c|c|c|c|c|c|c|c|c|}
\hline & ๓๐ & $\stackrel{n}{\stackrel{n}{s}}$ & ๒ొ & 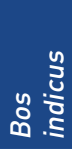 & ๓̊ & 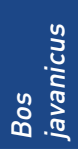 & $\begin{array}{l}\delta \delta \\
\frac{h}{n} \\
\frac{n}{2}\end{array}$ & 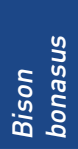 & $\begin{array}{l}\frac{n}{\pi} \frac{n}{\pi} \\
\frac{n}{3} \\
\frac{0}{3}\end{array}$ & 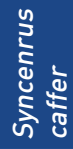 \\
\hline Bos mutus & 0.8 & & & & & & & & & \\
\hline Bos taurus & 8.0 & 7.9 & & & & & & & & \\
\hline Bos indicus & 7.7 & 7.6 & 1.6 & & & & & & & \\
\hline Bos gaurus & 6.7 & 6.8 & 7.6 & 7.2 & & & & & & \\
\hline Bos javanicus & 7.6 & 7.3 & 7.8 & 7.7 & 4.9 & & & & & \\
\hline Bison bison & 3.5 & 3.1 & 7.1 & 6.6 & 7.1 & 6.8 & & & & \\
\hline Bison bonasus & 6.9 & 7.1 & 6.3 & 5.8 & 6.9 & 7.7 & 6.7 & & & \\
\hline Bubalus bubalis & 12.0 & 12.1 & 12.9 & 12.8 & 12.6 & 12.8 & 12.1 & 11.9 & & \\
\hline Capra hircus & 15.1 & 15.1 & 14.8 & 15.0 & 16.0 & 16.5 & 15.4 & 15.1 & 15.0 & 14.0 \\
\hline
\end{tabular}

Table 3. Percentage of divergence for the control region in Bovinae and the outgroup

\begin{tabular}{|l|l|l|l|l|l|l|}
\hline & $\begin{array}{l}\text { Bos } \\
\text { grunniens }\end{array}$ & $\begin{array}{l}\text { Bos } \\
\text { mutus }\end{array}$ & $\begin{array}{l}\text { Bison } \\
\text { bison }\end{array}$ & $\begin{array}{l}\text { Bison } \\
\text { bonasus }\end{array}$ & $\begin{array}{l}\text { Bos } \\
\text { indicus }\end{array}$ & $\begin{array}{l}\text { Bos } \\
\text { taurus }\end{array}$ \\
\hline Bos mutus & 4.6 & & & & & \\
\hline Bison bison & 8.3 & 10.0 & & & & \\
\hline Bison bonasus & 13.0 & 13.2 & 13.2 & 12.5 & 6.1 & \\
\hline Bos indicus & 14.4 & 14.7 & 12.0 & 13.0 & 67.7 & 46.7 \\
\hline Bos taurus & 15.6 & 15.9 & 12.2 & 48.4 & & \\
\hline Capra hircus & 45.5 & 46.5 & 45.7 & & & \\
\hline
\end{tabular}


were identified in the present study. The number of polymorphic alleles ranged from 2 (ILSTS044) to 12 (TGLA122) with a mean number 5.1111 alleles per locus. The effective number of alleles was distinctively less than the observed alleles, ranging between 1.0832 (ILSTS044) and 6.5445 (TGLA122), with a mean of 3.1379 . The observed heterozygosity was less than the expected heterozygosity, which ranged from 0.0000 (INRA005, ILSTS044 and TGLA126) to 1.0000 (ETH152, MAF33 and MAF70) with an average of 0.4830 . The expected heterozygosities ranged from 0.0784 (ILSTS044) to 0.8645 (TGLA122) with mean a of 0.6195 , and a mean average heterozygosity to 0.6071 . Another parameter also indicative of genetic variation is the polymorphic information content (PIC), and according to this parameter, all loci may be considered highly informative. In the present study, PIC values varied from 0.07 (ILSTS044) to 0.83 (TGLA122), with average of 0.56 . Based on the PIC values, almost $67 \%$ of microsatellite markers were observed as highly informative (PIC $>0.50$ ) and $22 \%$ were logically informative $(0.50>$ PIC $>0.25)$ while only $11 \%$ were less polymorphic/informative (PIC $<0.25)$. The PIC analysis further indicated high utility of the set of markers used in this genetic

Table 4. Summary of genetic diversity statistics for all loci in yak

\begin{tabular}{|c|c|c|c|c|c|c|c|c|}
\hline Locus & $n a^{a}$ & $n e^{b}$ & $I^{c}$ & Obs_Het & Exp_Het & Ave_Het & $F_{15}{ }^{d}$ & $\mathrm{PIC}^{\mathrm{e}}$ \\
\hline BM1824 & 3.0000 & 2.4085 & 0.9487 & 0.6000 & 0.5967 & 0.5848 & -0.0260 & 0.49 \\
\hline BM1818 & 9.0000 & 5.0201 & 1.8745 & 0.3600 & 0.8171 & 0.8008 & 0.5504 & 0.78 \\
\hline BM2113 & 3.0000 & 1.8629 & 0.8128 & 0.3600 & 0.4727 & 0.4632 & 0.2228 & 0.42 \\
\hline BM6526 & 3.0000 & 2.8281 & 1.0684 & 0.4800 & 0.6596 & 0.6464 & 0.2574 & 0.57 \\
\hline CSSM66 & 3.0000 & 1.5133 & 0.6350 & 0.1600 & 0.3461 & 0.3392 & 0.5283 & 0.31 \\
\hline ETH10 & 5.0000 & 3.3693 & 1.3699 & 0.4800 & 0.7176 & 0.7032 & 0.3174 & 0.66 \\
\hline ETH152 & 4.0000 & 2.9412 & 1.1935 & 1.0000 & 0.6735 & 0.6600 & -0.5152 & 0.60 \\
\hline ETH225 & 5.0000 & 2.8217 & 1.2074 & 0.6800 & 0.6588 & 0.6456 & -0.0533 & 0.58 \\
\hline HAUT27 & 3.0000 & 1.1292 & 0.2652 & 0.0400 & 0.1167 & 0.1144 & 0.6503 & 0.11 \\
\hline ILSTS011 & 5.0000 & 3.6982 & 1.4081 & 0.4000 & 0.7445 & 0.7296 & 0.4518 & 0.68 \\
\hline ILSTS029 & 4.0000 & 2.2046 & 0.9979 & 0.6800 & 0.5576 & 0.5464 & -0.2445 & 0.49 \\
\hline ILSTS033 & 4.0000 & 2.8802 & 1.1661 & 0.4800 & 0.6661 & 0.6528 & 0.2647 & 0.59 \\
\hline ILSTS044 & 2.0000 & 1.0832 & 0.1679 & 0.0000 & 0.0784 & 0.0768 & 1.0000 & 0.07 \\
\hline ILSTS049 & 4.0000 & 2.3585 & 1.0201 & 0.5600 & 0.5878 & 0.5760 & 0.0278 & 0.49 \\
\hline ILSTS052 & 7.0000 & 2.2523 & 1.1947 & 0.2800 & 0.5673 & 0.5560 & 0.4964 & 0.53 \\
\hline INRA005 & 3.0000 & 1.9470 & 0.7790 & 0.0000 & 0.4963 & 0.4864 & 1.0000 & 0.40 \\
\hline INRA023 & 7.0000 & 4.1254 & 1.5855 & 0.5600 & 0.7731 & 0.7576 & 0.2608 & 0.72 \\
\hline INRA32 & 6.0000 & 3.5112 & 1.4814 & 0.4000 & 0.7298 & 0.7152 & 0.4407 & 0.68 \\
\hline INRA63 & 8.0000 & 4.5126 & 1.7033 & 0.6400 & 0.7943 & 0.7784 & 0.1778 & 0.75 \\
\hline MM12 & 3.0000 & 2.7778 & 1.0549 & 0.8000 & 0.6531 & 0.6400 & -0.2500 & 0.56 \\
\hline MAF33 & 7.0000 & 4.0584 & 1.6359 & 1.0000 & 0.7690 & 0.7536 & -0.3270 & 0.72 \\
\hline MAF70 & 7.0000 & 5.4348 & 1.8009 & 1.0000 & 0.8327 & 0.8160 & -0.2255 & 0.79 \\
\hline OarFCB48 & 5.0000 & 4.3554 & 1.5189 & 0.8800 & 0.7861 & 0.7704 & -0.1423 & 0.73 \\
\hline SPS115 & 7.0000 & 3.9185 & 1.5745 & 0.3200 & 0.7600 & 0.7448 & 0.5704 & 0.74 \\
\hline TGLA126 & 6.0000 & 3.8344 & 1.5197 & 0.0000 & 0.7543 & 0.7392 & 1.0000 & 0.70 \\
\hline TGLA227 & 3.0000 & 1.3312 & 0.4887 & 0.2000 & 0.2539 & 0.2488 & 0.1961 & 0.23 \\
\hline TGLA122 & 12.0000 & 6.5445 & 2.1207 & 0.6800 & 0.8645 & 0.8472 & 0.1974 & 0.83 \\
\hline Mean & 5.1111 & 3.1379 & 1.2072 & 0.4830 & 0.6195 & 0.6071 & 0.2045 & 0.56 \\
\hline
\end{tabular}

na ${ }^{\mathrm{a}}$ : observed num. of alleles, ne ${ }^{\mathrm{b}}$ : Effective num. of alleles, $\mathrm{I}^{\mathrm{c}}$ Shannon's information index, $\mathrm{F}_{\mathrm{IS}}{ }^{\mathrm{d}}$ : heterozygote deficit, PIC ${ }^{\mathrm{e}}$ Polymorphic information content 
analysis. Inbreeding coefficients for all microsatellite loci within the population in this study showed a heterozygote deficit, with mean value of 0.2045 .

\section{Discussion}

\section{Mitochondrial DNA analysis}

This study presents in detail the genetic variation at the partial mtDNA control region (695 bp) and Cyt $b$ gene (1609 bp) of 300 domestic yaks collecting from Gilgit-Baltistan and Skardu, i.e. northern regions of Pakistan. The objective was to determine the genetic structure, origin and domestication of Pakistani domestic yaks and elucidate the genetic relationship with other yaks in the region. It has been hypothesized that yaks were first domesticated by the ancient Qiang people on the QinghaiTibetan Plateau (Wiener et al., 2003). Though the exact date is unknown (Olsen, 1990), archaeological evidence suggests that $B$. grunniens were first domesticated some 5000 years ago (Cai and Wiener, 1995; Ning et al., 1997). The origin of current domestic yak in northern Pakistan has been investigated and a biphyletic origin proposed. We propose here that the current domestic yak in the region was likely derived from two distinct maternal lineages (A, B), followed by extensive gene flow between them. We confirmed the previous studies based on mtDNA D-loop sequences that suggested the two highly divergent lineages in both domestic and the wild counterpart (Tu et al., 2002; Qi et al., 2005; Guo et al., 2006; Lai et al., 2007; Ho et al., 2008). Pakistani yaks have been found to have a close phylogenetic relationship with, and may be considered a descendant of Chinese yaks. We propose that Pakistani yaks were not independently domesticated from the wild ancestor; however, it has been hypothesized that the current Pakistani yaks were domesticated when domestic yaks were transported from the southern slopes of the Himalayas to the northern highlands of Pakistan, where yak pastoralism was widespread through the mountainous Hindokush and Karakorum to other parts of GilgitBaltistan, Skardu to Chitral. Movement across the mountainous region is the only possible means of this expansion.

Other livestock, such as cattle, water buffalo and sheep, have shown two distinct divergent groups based on mtDNA clusters, possibly representing a dual domestication pattern. Loftus et al. (1994) observed two geographically distinct mtDNA clusters in cattle, one containing European and African cattle and the second clade containing Indian cattle. Similar to these ungulates, yaks appear to have also undergone a dual domestication pattern.

The Maximum-Likelihood tree based on 695 bp mtDNA control region showed that Pakistani yaks were divided into three haplogroups $A, C$, and $D$, of the six known haplogroups (A, B, C, D, E, and F). Haplogroup $A$ and $C$ were dominant, each with five sequences, while haplogroup D contained only one sequence. Our data indicated that there was no significant geographical structuring in Pakistani yak populations, suggesting evidence of strong gene flow, which is similar to the situation observed in domestic goat and sheep and probably reflects the mobile nature of yak. The result of weak phylogeographical and morphological structuring/correlations within Pakistani yaks is consistent with previous studies based on mtDNA (Bailey et al., 2000), microsatellite markers (Zhang et al., 2008), and blood protein electrophoresis (Tu et al., 1997).

Other studies have examined the taxonomic status of yak within Bovinae, though this is still a topic of debate. Some researchers consider the yak to be the subgenus Poephagus or a species of the genus Bos and there has been scrutiny con- 
sidering the proposal that yak should be the independent genus Poephagus within Bovinae. However, research based on descriptive characteristics, morphological traits, microsatellite polymorphism and mitochondrial DNA sequences analysis (Linnaeus 1766; Bohlken, 1961; Fan et al., 2000 and Ritz et al., 2000) have positioned the yak as a subgenus of Bos based on its morphological traits, while Gray, (1843), Corbet, (1978), Groves, (1981), Olsen, (1990, 1991), Geraads, (1992), Wiener et al. (2003), Li et al. (2006), and Qifa et al., (2007) have classified yak as an independent genus from Bos based on the study of the yak fossil record and characteristics of the skull bones. Wang, (2004) demonstrated the taxonomic status of yak, and his results were consistent with previous studies of Miyamoto et al. (1989), Hassanin and Douzery, (1999), Kraus et al. (1992) and Ward et al. (1999) using mitochondrial sequences, which revealed a closer phylogenetic relationship between yak and Bison than between yak and Bos. Li et al. (2005) constructed a phylogenetic analysis on the basis of exon2 of MHC DRB3, which revealed that the Bovinae clustered into five genera: Bos, Bison, Poephagus, Bubalus and Syncerus. Here, we retrieved the mitochondrial Cyt $b$ gene and control region of domestic Pakistani yaks to compare with Bison, Bos taurus and Bos indicus to conduct a phylogenetic analysis. On the basis of both mtDNA regions, tree topologies revealed that yak has a close genetic relationship with Bison (3.3\% and 9.15\% divergence on the basis of Cyt $b$ gene and D-loop, respectively) and a more distant relationship with other bovid species. Bootstrap support for each lineage and cluster for validity of the grouping. Ideally, supports less than $50 \%$ are not considered valid clusters or clades. The mean percentage of nucleotide sequence divergence between yak and American Bison bison was much lower than between yak and Bos (Bos taurus and Bos indicus) at $7.8 \%$ (Table 3 ). Phylogenetic analysis revealed that Bos grunniens and Bos mutus clustered in one branch, indicating a higher genetic similarity between those two species and a closer phylogenetic relationship than those between Bos grunniens and Bos taurus, which clustered into another branch. The same proposition was observed on the basis of mitochondrial D-loop sequence analysis; the average percentage of nucleotide sequence divergence between yak and American Bison bison was much lower than yak and Bos (Bos taurus and Bos indicus) at 15.75\% (Table 4), also showing the close genetic affiliation between Bison and yak.

\section{Microsatellite analysis}

Autosomal microsatellite markers are another class of molecular markers extensively used in evolutionary and population genetic studies of livestock species. A sample of 27 cattle-derived autosomal microsatellite markers were used to amplify genomic DNA extracted from 30 yaks (Bos grunniens). All microsatellite loci were successfully amplified by PCR on yak genomic DNA, and all markers (100\%) were polymorphic. Polymorphic information content (PIC) is a more efficient index of weighing polymorphism of the fragment. Genetic markers with PIC values of less than 0.25 are considered less informative and those with values more than 0.5 are consider distinctly informative in population genetic studies (Botstein et al., 1980). Accordingly, in the present study, 3 of 27 microsatellite markers showed PIC values lower than 0.25 (ILSTS044 (0.07), HAUT27 (0.11) and TGLA227 (0.23)). The marker TGLA227 was found to be highly polymorphic by Nguyen et al. (2005), Sujun et al. (2004) in Swiss yaks (0.79) and Chinese yaks (0.51), respectively. With the exception of INRA005 (0.40), ILSTS029 (0.49), ILSTS049 (0.49), CSSM66 (0.31), BM1824 (0.49) and BM2113 (0.42), all the remaining 18 loci were highly 
informative with PIC values greater than 0.5 , indicating their suitability for assessing genetic variation.

Nguyen et al. (2005) studied 131 bovine microsatellite markers on a panel of ten animals, in which 117 markers were polymorphic and the PIC ranged from 0.35 to 0.75 , which overlaps with our values of 0.07 to 0.83 . The mean PIC value 0.56 in our study is greater than 0.54 as studied by Qifa et al. (2004) and lower than 0.65 in Chinese yak studied by Sujun et al. (2004).

The observed number of alleles and the allele range was observed as 5.1111 and 2 to 12, respectively in this study, which was higher than the Swiss yak with 3 to 9 alleles (Nguyen et al., 2005) and comparable with two Chinese yak Gannan (5.2) and Datong (5.3 alleles) that used a set of 12 microsatellite markers (Minqiang et al., 2003). Qifa et al. (2004) used a set of 20 microsatellite markers for amplification in 143 yaks from 6 breeds (Tianzhu, Jiulong, Datong, Maiwa, Lhasa, and semi-wild) in China. The mean number of alleles (MNA) ranged from 4.5 to 6 , which is comparable with the mean value of our study, suggesting that Pakistani domestic yaks are not in the genetic lineage of Chinese yaks.

However, the mean observed heterozygosity $(0.4830)$ was lower than the expected heterozygosity (0.6195). This could be due to population subdivision in each region and local inbreeding. Population subdivision may occur because of the geographical isolation of yak herds. The average heterozygosity value (0.6071) was slightly lower than the value (0.6625) obtained for the Chinese yak population by Sujun et al. (2004) and higher than the value (0.4791) obtained for the Chinese yak population by Qifa et al. (2004). F $_{\text {IS }}$ heterozygote deficit) was significantly positive with a mean value of 0.2045 , indicating a high inbreeding coefficient in the present study of yak; this may be due to close geographical locations of yak population.

The applicability of bovine microsatellite markers has been reported in a number of genetic studies of various species and shows the extensive genomic conservation of cattle microsatellite DNA sequences during evolution. All 27 cattle microsatellite markers were sequenced in the yak genome and polymorphism was found at all loci. Similar results were obtained using 12 cattle microsatellite markers in 48 Chinese yaks by Minqiang et al. (2003). Nguyen et al. (2005) tested 131 bovine microsatellite markers in a panel of ten Swiss yaks, observing amplification for 124 markers and found $94.3 \%$ were polymorphic, and the similarly markers used in our study confirmed the results. The conservation of cattle microsatellite loci in the yak genome, as illustrated in our results, indicate a high applicability of bovine microsatellites for genetic diversity, relationship and parentage analysis in yak and can be used for future genetic studies for this important Asian species.

\section{Conclusions}

In conclusion, the possible origin, evolutionary history, molecular phylogeny, and selection evidence of domestic yaks (Bos grunniens) in Pakistan were explored in this study. The results provided contributions to the existing knowledge about these yaks and evaluated their uniqueness.

\section{References}

1. BAILEY, J. F., B. HEALY, H. JIANLIN, L. SHERCHAND, S. L. PRADHAN, T. T. SENDSUREN, J. M. FOGGIN, C. GAILLARD, D. STEANE, I. ZAKHAROV and D. G. BRADLEY (2000): Genetic variation of mitochondrial DNA within domestic yak populations. Proceeding of the third international congress on yak. Lhasa P.R. China, 4-9 September 2000.

2. BABAR, M. E., T. HUSSAIN, M. IMRAN, M. NAGARAJAN and S. KUMA (2011): Mitochondrial DNA diversity patterns in Pakistani buffalo. Anim. Genet. 42, 1365-2052. 
3. BOTSTEIN, D., R. L. WHITE, M. SKOLNICK and R. W. DAVIS (1980): Construction of a genetic linkage map in man using restriction fragment length polymorphisms. Am. J. Hum. Genet. 32, 314-331.

4. BOYCE, W. M., P. W. HEDRICK, N. E. MUGGLICOCKETT, S. KALINOWSKI, M. C. PENEDO and R. R. RAMEY (1996): Genetic variation of major histocompatibilty complex and microsatellite loci: a comparison in Bighorn sheep. Genetics 145, 421-433.

5. CARMELA, G., A. REYES, G. PESOLE and C. SACCONE (2000): Lineage-Specific Evolutionary Rate in Mammalian mtDNA. Mol. Biol. Evol. 17, 1022-1031.

6. CORBET, G. B. (1978): The mammals of the Palaearctic Region: A taxonomic review. British Museum (Nat Hist).

7. FAN, B. L., N. LI and C. X. WU (2000): Research on constructing phylogenetics trees of ruminants based on the database of milk protein gene sequences. Acta Genetic Sinica 27, 485-497.

8. FENG, Z. J., G. Q. CAI and C. L. ZHENG (1986): The Mammals of Tibet. Beijing: Science Press.

9. GERAADS, D. (1992): Phylogenetic analysis of the tribe Bovini (Mammalia: Artiodactyl). Zool. J. Linnean Sot. 104, 193-207.

10. GRAY, J. E. (1843): List of the Specimens of Mammalia in the Collection of the British Museum. London: The Trustees.

11. GROVES, C. P. (1981): Systematic relationships in the Bovini (Artiodactyla: Bovidae). Z. Zool. Syst. Evolut-forsch. 19, 264-278.

12. GUO, S., P. SAVOLAINEN, J. SU, Q. ZHANG, D. QI, J. ZHOU, Y. ZHONG, X. ZHAO and J. LIU (2006): Origin of mitochondrial DNA diversity of domestic yaks. BMC Evol. Biol. 6, 73.

13. HASSANIN, A. and E. J. P. DOUZERY (1999): Evolutionary affinities of the enigmatic saola (Pseudoryx nghetinhensis) in the context of the molecular phylogeny of Bovidae. Proc. R. Soc. Lond. 266, 893-900.

14. JANSEN, T. P., M. A. FORSTER, H. LEVINE, M. OELKE, C. HURLES, M. RENFREW, J. WEBER and K. OLEK (2002): Mitochondrial DNA and the origins of the domestic horse. Proc. Natl. Acad. Sci. USA 99, 10905-10910.

15. KIERSTEIN, G., M. VALLINOTO, A. SILVA, M. P. SCHNEIDER, L. IANNUZZI and B. BRENIG (2004): Analysis of mitochondrial D-loop region casts new light on domestic water buffalo (Bubalus bubalis) phylogeny. Mol. Phylogenet. Evol. 30, 308-324.

16. KIKKAWA, Y., T. AMANO and H. SUZUKI (1995): Analysis of genetic diversity of domestic cattle in east and southeast Asia in terms of variations in restriction sited and sequences of mitochondrial DNA. Biochem. Genet. 33, 51-55.

17. KRAUS, F., L. JARECKI, M. M. MIYAMOTO, S. M. TANHAUSER and P. J. LAIPIS (1992): Mispairing and compensational changes during the evolution of mitochondrial ribosomal RNA. Mol. Biol. Evol. 9, 770-774.

18. LARSON, G., K. DOBNEY, U. ALBARELLA, M. Y. FANG, E. MATISOO-SMITH, J. ROBINS, S. LOWDEN, H. FINLAYSON, T. BRAND, E. WILLERSLEV, P. ROWLEY-CONWY, L. ANDERSSON and A. COOPER (2005): Worldwide phylogeography of wild boar reveals multiple centers of pig domestication. Science 307, 1618-1621.
19. LAU, C. H., R. D. DRINKWATER, K. YUSOFF, S. G. TAN, D. J. HETZEL and J. S. BARKER (1998): Genetic diversity of Asian water buffalo (Bubalus bubalis): mitochondrial DNA D-loop and cytochrome b sequence variation. Anim. Genet. 29, 253-64.

20. LI, Q. F., Y.H. LI, X.B. ZHAO, X.B. LI, Z.X. PAN, Z. XIE and N. LI (2005): Sequence variation at exon2 of MHC DRB3 locus in Bovinae. J. Agri. Biotech. 13, 441-446.

21. LI, Q. F., X. B. ZHAO, H. L. LIU, N. LI and Z. XIE (2006): A review of the research on taxonomic position in yak (Poephagus). Acta Zootaxonomica Sinica 31, 520-524.

22. LINNAEUS, C. (1766): Systema naturae sive regna tria naturae, secundum classes, ordines, genera, species, cum characteribus, differentiis, synonymis, locis. $12^{\text {th }}$ ed. Holmiae: Laurentii Salvii Bohlken $\mathrm{H}$ (1961). Haustiere und Zoologische Systematik. Z Tier. Zuchtungsbiol. 76, 107-113.

23. LOFTUS, R. T., D. E. MAVHUGH, L. O. NGERE, D. S. BALAIN, A. M. BADI, D. G.BRAKLEY and D. P. CUNINGHAM (1994): Mitochondrial genetic variation in European, African and Indian cattle populations. Anim. Genet. 25, 267-271.

24. LUIKART, G., L. GIELLLY, L. EXCOFFIER, J. D. VIGNE, J. BOUUVET and P. TABERLET (2001): Multiple maternal origins and weak phylogeographic structure in domestic goats. Proc. Natl. Acad. Sci. USA 98, 5927-5932.

25. MILLER, D. J. and D. E. STEANE (1997): Conclusions. In: Proceedings of a Workshop on Conservation and Management of Yak Genetic Diversity Held at ICIMOD, Kathmandu, Nepal, 29-31 October 1996 (Ed. By D. G. Miller, S. R. Craig \& G. M. Rana), pp. 191-209. ICIMOD, Kathmandu, Nepal.

26. MINQIANG, W., S. WEIGEND, A. BARREDIRIE, J. W. CARNWATH, L. ZHONGLIN and H. NIEMANN (2003): Analysis of two Chinese yak (Bos grunniens) populations using bovine microsatellite primers. J. Anim. Breed. Genet. 120, 237-244

27. MIYAMOTO, M. M., S. M. TANHAUSER and P. J. LAIPIS (1989): Systematic relationship in the artiodactyl's tribe Bovini (family Bovidae), as determined from mitochondrial DNA sequences. Syst. Zool. 38: 342-349.

28. NGUYEN, T. T., S. GENINI, F. M. TREY, M. MALEK, P. V. GELI, M. R. GOE and G. STRANZINGER (2005): Application of bovine microsatellite markers for genetic diversity analysis of Swiss yak (Poephagus grunniens). Anim. Genet. 36, 484-489.

29. OLSEN, S. J. (1990): Fossil ancestry of the yak, its cultural significance and domestication in Tibet. Acad. Nat. Sci. Phila. 142, 73-100.

30. OLSEN, S. J. (1991): Confused yak taxonomy and evidence of domestication. Illinois State Museum Scientific Papers. 23, 387-393.

31. QIFA, L., Z. XINGBO, L. YANHUA, L. NING, W. CHANGXIN and X. ZHUANG (2004): Construction of microsatellite-enriched library of yak and phylogenetic study of six Chinese yak populations using yak-specific microsatellites. Proceedings of the International Congress on Yak, Chengdu, Sichuan, P.R. China 2004

32. RAYMOND, M. and F. ROUSSET (1995): An exact test for population differentiation. Evolution. 49, $1280-1283$. 
33. RITZ, L. R., M. L. GLOWATZKI-MULLIS, D. E. MACHUGH and C. GAILLARD (2000): Phylogenetic analysis of the tribe Bovini using microsatellites. Anim. Genet. 31, 178-185.

34. SAVOLAINEN, P., Y. P. ZHANG, J. LUO, J. LUNDEBERG and T. LEITNER (2002): Genetic evidence for an East Asian origin of domestic dogs. Science 298, 1610-1614.

35. SUJUN, Z., Z. JINCHENG, Z. SHENG, Z. QIN and H. KAI (2004): Analysis of microsatellite loci in yak. Proceedings of the International Congress on Yak, Chengdu, Sichuan, P.R. China 2004.

36. TAMURA, K., G. STECHER, D. PETERSON, A. FILIPSKI and S. KUMAR (2013): MEGA6: molecular evolutionary genetics analysis version 6.0. Mol. Biol. Evol. 30, 2725-2729.

37. TROY, C. D., D. E. MACHUGH, J. F. BAILEY, D. A. MAGEE, R. T. LOFTUS, P. CUNNINGHAM, A. T. CHAMBERLAIN, B. C. SYKES and D. G. BRADLEY (2001): Genetic evidence for Near-Eastern origins of Europe cattle. Nature 410, 1088-1091.

38. TU, Z. C., H. QIU and Y. P. ZHANG (2002): Polymorphism in mitochondrial DNA (mtDNA) of yak (Bos grunniens) Biochem. Genet. 40, 187-193.

39. TU, Z. C., Y. P. ZHANG and H. QIU (1997): Genetic diversity and divergence in Chinese yak (Bos grunniens) populations inferred from blood protein electrophoresis. Biochem. Genet, 35, 13-16.

40. WANG, L. (2004): Study on mitochondrial DNA diversity and genetic divergence of Chinese yak.
Dissertation for the Master Degree. Ya'an: Sichuan Agricultural University, 39-40.

41. WANG, Z., S. XIN, B. LIU, J. SU, T. YONEZAWA, Y. YU, S. GUO, Y. SIMON, C. VILA, M. HASEGAWA and L. JIANQUAN LIU (2010): Phylogeographical analyses of domestic and wild yaks based on mitochondrial DNA: new data and reappraisal. J. Biogeogr. 37, 2332-2344.

42. WARD, T. J., J. P. BIELAWSKI, S. K. DAVIS, J. W. TEMPLETON and J. N. DERR (1999): Identification of domestic cattle hybrids in wild cattle and bison species: A general approach using mtDNA markers and the parametric bootstrap. Anim. Conserv. 2, 51-57.

43. WIENER, G., H. JIANLIN and L. RUIJUN (2003): The Yak, $2^{\text {nd }}$ edn., Bangkok: Regional Office for Asia and the Pacific, Food and Agriculture Organization of the United Nations.

44. YEH, F. C. and R. YONG (1999): POPGENE version 1.31: Microsoft-based Freeware for Population Genetic Analysis. University of Alberta, Edmonton, Canada.

45. ZHANG, G. X., W. S. CHEN, M. XUE, Z. G. WANG, H. CHANG, X. HAN, X. J. LIAO and D. L. WANG (2008): Analysis of genetic diversity and population structure of Chinese yak breeds (Bos grunniens) using microsatellite markers. J. Genet. Genomics $35,233-238$.

\section{Molekularna filogenija i genetička raznolikost domaćih jakova (Bos grunniens) u Pakistanu na temelju mitohondrijskih i mikrosatelitskih markera}

Tanveer HUSSAIN, Abdul WAJID, Akhtar ALI, Kamran ABBAS, Masroor Ellahi BABAR, Zavod za molekularnu biologiju, Virtual Univerzitet u Pakistan, Lahore, Pakistan; Mudassir SOAIL, Zavod za stočarstvo i mljekarstvo, Gilgit Baltistan, Pakistan; Faiz M. M. T. MARIKAR, General Sir John Kotelawala Defense Univerzitet, Ratmalana, Šri Lanka; Zavod za zdravstveno obrazovanje i istraživanje, The Open Univerzitet u Šri Lanci; Muneeb M. MUSTHAFA, Zavod za tehnološke biosustave Fakultet Tehnologije, South Eastern Univerzitet u Šri Lanci, Univerzitet Park, Oluvil, Šri Lanka

Za pakistanskog domaćeg jaka (Bos grunniens) iz obitelji šupljorožaca (Bovidae), sekvenciran je cjelokupni citokromni b gen i djelomice kontrolna regija mtDNK. Genotipizirano je tri stotine uzoraka uporabom 27 goveđih mikrosatelitskih markera pasmine Gilgit-Baltistan i Skardu iz Pakistana. Identificirali smo ukupno 35 mutacija i 9 haplotipova na temelju sekvencija D-petlje uz haplotipsku i nukleotidnu raznolikost od $0,9640 \pm 0,051$, odnosno $0,02172 \pm 0,00224$. Za citokromni $b$ gen, ukupno 23 varijabilne lokacije i šest različitih haplotipova zamijećeno je $s \quad 0,885 \pm 0,067$ haplotipskom i 0,00989 $\pm 0,003$ nukleotidnom raznolikošću. Filogenetska analiza D-petlje i citokromnog $b$ gena ukazala je da se sekven- ce domaćih jakova grupiraju u dvije vrlo divergentne loze po majci (loza I i II), dok su identificirane tri haplogrupe $\mathrm{A}, \mathrm{C}$ i D od ranije poznatih šest haplogrupa. Haplogrupe A i C bile su dominantne i široko rasprostranjene među svim istraženim uzorcima jakova. Svi mikrosateliti bili su polimorfni te je zamijećeno ukupno 138 alela, s prosječnim sadržajem polimorfne informacije (PIC) od 0,56 ukazujući na njihovu učinkovitost. Zamijećena je prosječna heterozigotnost od 0,6071 s alelnom raznolikošću 5,1111 i genetskom raznolikošću 0,4830 . Implikacije ovih nalaza mogu se rabiti za očuvanje populacije jakova.

Ključne riječi: domaći jak, mtDNK petlja, citokromni b gen, mikrosateliti, filogenija, Pakistan 